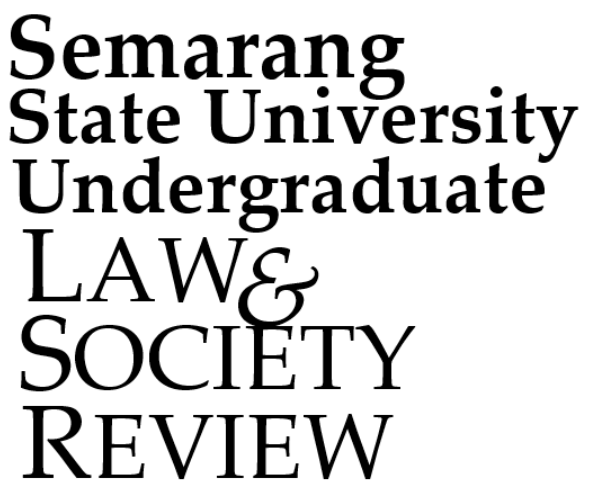

VOLUME 1 ISSUE 1, JANUARY 2021
ISSN (Print): 2807-8225 ISSN (Online): 2807-8683

\author{
History of Article \\ Submitted: November 2020 \\ Revised: December 2020 \\ Accepted: January 2021
}

How to cite:

Rahmatika, A. V. (2021). Violence on Women and Children: Background, Effects, and Solutions. Semarang State University Undergraduate Law and Society Review, 1(1), 69-86. https://doi.org/10.15294/lsr.v1i1.49840

(C) 2021 Authors. This work is licensed under a AttributionNonCommercial-ShareAlike 4.0 International (CC BY-NC-SA 4.0). All writings published in this journal are personal views of the authors and do not represent the views of this journal and the author's affiliated institutions.

\title{
Violence on Women and Children: Background, Effects, and Solutions
}

\author{
Aulia Vaya RAHMATIKA® \\ Universitas Negeri Semarang \\ Jl. Kampus Timur, Sekaran, Gunungpati, Semarang, INDONESIA \\ 凶auliavaya15@gmail.com
}

\begin{abstract}
Violence is any criminal conduct that may harm the victim. The violence occurred on a number of factors, including the factors economic, cultural, social, and legal. Today, violence is an awful lot going on in the community. See the rampant violence lately are influenced by the large number of people experiencing prolonged crisis due to oppression. The action also triggered by weak social control that is not followed by legal enforcement measures. There is also the violence done to women and children. Violence against women as a global problem, already fretting over every country in the world, not just the countries that are developing but also including developed countries which are said to be greatly
\end{abstract}


appreciate and care about the human rights as United States of America. Indonesia as a country that is growing, it bore the title bad in the problem of human rights violations. Human rights violations are one of which violations of women's human rights. The women's human rights violations can be classed as acts of violence against women. Violence against women may occur anywhere (in a public place, in the workplace, the surroundings of family (household) and others. Can be done by anyone (parents, brothers or women and others and can occur at any time (day and night). In addition, the violence that occurs in children also resulted in mental decline. Children will feel depressed and prolonged trauma. It is certainly harmful for the child's mental and psychic condition. Violence in children usually occurs because a child who is misbehaving and not according towards parents so often parents furious and do acts of violence. This I will discuss to uncover cases of violence on women and children.

KEYWORDS. Women Protection; Children Protection; Violence

\section{INTRODUCTION}

It has been reasonably mutually friendly hospitality and our fellow human beings and keep one another. Moreover, with fellow members of her family. The family is a haven to receive affection and support for existing members. But the affection and support it has overshadowed the presence of violence in the household. The various acts of violence occur that victims are women and children. Normatively, the government has the basic authority to execute death. Among others are in Law Number 1 of 1946 About the Criminal Code, Law Number 2 PNPS in 1964 Concerning the Procedures for the Criminal Implementation Done by Courts within the General and Military Court, enacted by Law Number 5 of 1969, and Law 
Number 8 of 1981 about KUHAP (Indonesian Criminal Procedural Code, 1981).

Already within a country should be required for the protection of women and children. Who often become victims of violence? Women and children as a group in society in a country that is obliged to obtain the guarantee of the protection of human rights. In the Convention elimination of discrimination of women there are 30 articles, including five of the first articles contains the rationale elimination of discrimination against women and the obligation that must be carried out by the Government. Article 616 contains the substantive rights and obligations of the Government. Article 17-30 contains provisions concerning institutional structure, procedures, and reporting mechanisms the implementation of convention ratification and accession the Convention, and in the event of a dispute regarding the application and interpretation of the Convention (Alfitri, 2020; Putra, 2019). There are some rules governing the protection of the child. Among them, Act 35 of 2014 a change from article 23 of the year 2002 on the protection of children Act No. 17 of 2016 and Perda No. 3 of 2014 could work together to protect women and children from violence, sexual crimes, as well as human trafficking. Some of these rules are created to protect women and children (Sitorus, 2019).

But, in fact many still found cases of acts of violence on children and women. Many cases of children being the victims of violence to death. Not only children, but many women also found lifeless already discarded due to victims of violence. More pitiful a lot of people know that such behaviour is inappropriate but still many people close their eyes as if they never see it. In fact, doing acts of violence. Through this research, the understanding of the people about the violence that is often the case, why are women and children who usually become victims as well as men are 
usually the perpetrators of the violence (DeKeseredy, 2020; Krahé, 2018; Rumble, et.al., 2020).

The research process is a series of interrelated method to try to resolve the problems that often occur especially discussed here i.e., violence on children and women. In "the idea of a special Domestic Violence Courts" (2017). In the criminal justice system in Indonesia at the moment, SPPTPKKT can be realized in various ways to prevent violence on women and children. Among them, 1.) the existence of a public participation case against violence on women. 2.) the existence of human resources who understand the root of the problem of violence on a woman so able to give services when handling the victims or perpetrators. 3.) the existence of a level every PRK Polsek so that the problem of violence on women and children that occurs can be handled. 4) the existence of a network with the media in monitoring the handling of cases of violence on women and children (Helmi, 2017).

Research Strategy: the research methods used by investigators in the case of violence on women and written in his book "violence against a wife" (2002). This study uses qualitative methods are pure in the focus and uses the interpretation naturally against the principal problems are examined. The selection of this method is considered appropriate because researchers wanted to examine this issue in a natural setting. The researcher is resorting to interpret and construe what is perceived by the informant. Here researchers using subject research i.e., the women who work, especially the women who work in the field of education, namely teachers and professors. Researchers using the technique of research sampling and purposive snowball that is based on the theory of non-responsibility. With this technique the individual does not has a surface equal right to be selected into the sample. In this study a sample intended to provide data (Fathul, et.al., 2002). 
It is intended to invite the community to more sensitive and caring toward fellow to protect. In order to prevent cases of violence against children and women. As well as protecting the women and children which is vulnerable creatures that need to be protected. So as not to cause more casualties. Here researchers using subject research i.e., the women who work, especially the women who work in the field of education, namely teachers and professors. Researchers using the technique of research sampling and purposive snowball that is based on the theory of nonresponsibilities. With this technique the individual does not has a surface equal right to be selected into the sample. In this study a sample intended to provide data. In the book "Introduction to Criminology" (2013), to examine the cases of violence on children and women researchers using several methods.

1) Evidence-based Research

A fundamental study on the effort to use the knowledge and the evidence examined properly. Using evidence-based research approach to problem resolution by leveraging a variety of evidence from national and international

2) Survey against victims

Survey against the victim is specifically designed to take down victimizes indicated by the sample representative

3) crime criminal victimizes survey (Hagan, 2013).

Data Collection and Analysis Methods:

1) The study documents

The first step is to analyze documents concerning cases of violence on children and women

2) The Forum Group Discussion (FGD)

The interview focused on one group that never had the forms of violence. 
3) In-depth Interview

Using the method of semi structure interview not a structured interview in order to control the information obtained from informants.

In this study using three sub processes to analyze data. Among them, the reduction of data, display data, conclusion, and withdrawal (Miles \& Huberman, 1994). Through the reduction of data by way of doing data compaction selection dan then summarized and coded. The data is then displayed in the summary as well as the research structured in order for possibilities to be drawn the conclusion. After that the next step is to draw conclusions and to verify the data.

\section{DEVELOPMENT OF VIOLENCE AGAINTS WOMEN AND CHILDREN}

The issue of violence against women can have an impact on the incidence of violence to women, children, even the country (Sitorus, 2019). Violence is unlawful acts for violating human rights by giving the bad impact towards the victim. In addition, it can affect the victim's Psychology gives a sense of trauma that are difficult to cure. And provide a sense of fear and worry about the environment. Violence can occur due to an altercation between two or more parties are ongoing and no one wants to budge and each other feel that her truest. As for the cause of other factors:

1) An individual who has difficulty controlling emotions

2) A sense of love to blame others

3) The existence of a problem that creates animosity

4) The existence of a social gap that makes people become arbitrarily

5) The lack of a sense of appreciating each other

Violence can be differentiated into two, namely violence perpetrated by individuals and the violence perpetrated by the group. Violence that 
can cause misery for individuals both physically and psychology. Violence can cause trauma to the individual. Usually, the perpetrator of violence is an individual who ever got in his past acts of violence or have witnessed acts of violence. This led to prolonged trauma for the victims. It also will cause a disruption of the victim soul mental violence. Based on research, alcoholic beverages can lead to violence. Because of the content that is in the alcohol affects the emotions a person to commit acts of violence. On the other hand, ridicule against someone can give rise to feelings of resentment that will trigger the existence of acts of violence against others.

Violence perpetrated by certain groups as community social groups cause inequality of social violence. There are social groups that are not regularly cause spontaneous violence. So, the victims being easily influenced and sentiment. Violence can cause hazard for the impact of their victims. Violence can be defined as the principle of the fundamental act itself on the power to force the other party without approval (Lardellier, 2003; Haryomotko, 2007) violence looks like a representation of evil inflicted on men, but he could also do towards others (Haromotko, 2007). So, the violence not only in physical form but can be in the form of a psychic in destroying one's life. Like for example, prolonged trauma experienced by the victims can be badly of life onwards.

In everyday life we often find plenty examples of acts of violence, especially in the media, inviting interest. As in the film, broadcast, advertising, and fiction in the entertainment industry the purpose of raising the rating their programs in order to achieve success in the competition of the world industry. But, resulting in harm to the audience is primarily children under that still need parental controls. Because, today many parents neglect watching his son, so many children that imitate a violent scene as aired on $t v$ with the intent to follow the example of their idol without them knowing the impact of such a feat that can take the 
impact bad for victims. The main difficulty is to determine the limits of violence in media that can be tolerated. Need to set the extent to which the media has the right to present. Because the current spate of abuse in the use of the media. Need for guidance to parents in supervising her son so as not happening things unwanted such as acts of violence.

In addition, the influence of globalization also causes high acts of violence in social media. As such, the existence of a speech-speech of hatred that can make a person feel depressed and stressed out. Speech is distorted with norms and could be said to be human rights violations. And may give rise to a sense of hate in a person.

There are various forms of violence. Namely nonviolence and physical violence is physical.

1) Physical violence

Violence that seemingly obvious. Because of the touch between the perpetrator and the victim. Example: hitting, kicking, stomping, slapping, etc.

2) Nonphysical Violence

Violence not clearly seen in, because there is no touch between the perpetrator and the victim. The nonphysical violence can be divided into two forms, namely the verbal violence and psychic/psychological violence.

a. Verbal Violence

The violence that was done using words. Example: defamatory, snap, shout at, spreading gossip, accuse, etc.

b. The psychic Violence/psychology

Violence is done through body language. Example: looked at cynically, humiliate, isolate, silence, etc. 


\section{A. Violence in Women}

Violence on women is violence which violates human rights, because of the demeaning gender females. The violence badly life of women in terms of physical, psychological, or sexual. It also included threats and coercion which arbitrarily both in personal life and society. All forms of genderbased violence that resulted or may result in, harm physically, sexually, mentally or suffering to women, including threats of such acts, coercion, or deprivation of freedom, arbitrarily good happening surroundings community as well as personal life (UN Declaration on Anti-Violence Against Women, Article 1, 1983).

Violence in women can be caused by several factors, among them are cultural factors. In our culture are still putting the boy in a higher position and women in low position. In terms of decision making of the man who is more important to determine the decision than women. This has resulted in reduced the rights of a woman which led to violence. In addition to cultural factors, there are also other factors economic factors, namely, the existence of economic dependence of women who have no income of her own against the men. Because it makes men feel a higher degree. And felt entitled to do arbitrary. The occurrence of early marriage can make the incidence of violence in it. Due to the immature age makes someone less able to control his emotions. Feelings are still passion in young immature to make her feel what it does is always right and would not budge (Wicaksono \& Lestari, 2020).

In addition, the attitude of the wife who does not appreciate the husband can trigger the onset of the violence. In fact, every human being wants to feel that he appreciated. What's a husband who wants to feel privileged by his wife (Setiawan, Saifunuha, Kautsar, Wulandari, 2019). As 
well as the status of the husband as head of household. Forms of domestic violence, such as:

1) Physical violence: physical violence can be painful. Example: hitting, slapping, and kicking

2) Psychic Violence: violence perpetrated through body language. Example: shouted and snapped

3) Sexual violence: violence is doing the action in the direction of sex or sexually insistence. Sexual violence can be differentiated into eight kinds, namely sexual harassment, sexual exploits, marital rape, coercion, coercive sterilization, sexual slavery, forced prostitution, sexual torture for example: invite touch sex without consent of victims, making the victim without his approval to become a commercial worker

4) Financial Violence: violence in it does not satisfy the material. Example: don't give a living or make ends meet.

5) Spiritual Violence: devalue or ignore the victims, forcing the belief performs a ritual, and forced to follow a flow without based on the wishes of the victim.

When violence continued to occur, then the woman will always be disadvantaged because of his right as a human being deprived. Therefore, violence on women must be prevented so as not to cause more casualties. To prevent acts of violence on a woman can be done several ways, i.e., first, arouse the public to care more about against violence on women. Because of this very problem needs to be addressed in order to protect women. Secondly, to equip women how to keep safety themselves. Third, report to the appropriate authorities. Because there are still many people recognized that cases of domestic violence are a social case must be covered from the public because it is a disgrace, but cases of domestic violence are that the case should be dealt with as many adverse impacts (Setyowati \& Rusdiana, 2020). 


\section{B. Violence in Children}

Violence on children is an action and torture both physically, emotionally, and neglect to the child. Violence committed against not only adults but also children. It was recorded that the 45 to $70 \%$ tormentor who had also tormented his own son (Subhan, 2001). many older people do violence to prevent undesirable behaviour. Because by using violence and the threat of parents think that the most effective way to make children become obey what others are saying. But with the violence may give an example to the children that to resolve the problem of bias using violence (Izat, 2020; Latifiani, 2019). Many children who become violent especially in his family when outdoors will vent his emotions and forms of violence on others. Even the children who became victims of violence when they have children, they will do it that way as well to his son. Many things that trigger the onset of violence to the child, among others:

1) The scope of the violence. Someone who had experienced violence in his childhood, will repeat it when adults because they think it is normal that they often felt first.

2) Felt stress. Because being a parent is not an easy thing. Many parents who have high ideals for his son, but the child is not able to meet the target of parents, so parents are using threats and coercion in order for the child in accordance with the desired parent. In addition, the work that made the parents stress and fatigue can make parents vent to his emotions to his son.

3) The existence of a tendency on alcoholic drinks and drugs. A person who is under the influence of alcohol and drugs tend to be more difficult to control emotions.

4) State of the economy of the family. Families with a low economic background, making the husband as head of household stress cannot 
meet the needs of his family. From this he felt stress followed by a cranky child could be the trigger for the onset of the violence.

5) Family circumstances that are not harmonious. The occurrence of a quarrel between husband and wife, and the lack of love in the family.

There are many forms of violence to children.

1) Physical Torture

Many parents argue that by using physical violence can make children more discipline, but in reality, it is impacting on the lives of both current as well as future later

2) Sexual Harassment

In the age of now many children who became victims of impingement sexual parents.

3) Torture with emotion

With parent's underestimate, snap the child continuously can make a child feel depressed.

4) Lack of time for children or leaving children alone

Parents who are too busy working, make them do not care about their children. Sometimes they think meet the needs in the material is sufficient. But they do not know that a child is more needed attention from his parents.

Violence against children can affect the future of a child. They can just feel the lingering trauma and could thus be perpetrators of violence because of a sense of revenge that he so far become victims of the violence. Violence can be prevented by various means, one of which is the strengthen of the relationship between the parents. Make children feel comfortable and open with his parents (Elmira, 2020). Do discussions between parents and children for a few problems can make children feel themselves more appreciated. Whatever time works, take the time for a child. Because the parents of badly needed attention to the child. The attention of the parents can be a support for the child in determining the 
future. When children make mistakes, give a wise sentence, not just to punish him with based on emotion and then violence. Because it will always be remembered by children and could affect his personality.

\section{CONCLUSION}

From what has been described above, then it can be inferred that there was still violence that exists in Indonesia, which is the percentage of the violence that is high enough to occur in children and women. As for some of the factors that influence such as economics, the environment, and the culture. Indonesia already has laws governing violence against children and women, but the implementation has not been adequate in Indonesia. Hence the need for a review of that Act. The review may use the personal approach towards the individual, otherwise it is need for counselling and accompaniment for the victims of violence, as victims who experience violence certainly has psychological as well as against the trauma of physical also. One of the things or the most easy and simple to do when there is violence as violence on the child or family member, you as a witness or at least members of the environment must be responsive and mandatory for prevent accidents and incident, by way of approaching someone with questioning things that are not related to the problem, but you have to come with a group of powerful or have quantity more, so violence will happen and causes emotions that someone humble. The bottom line is we as social beings to support legislation that has been formed by the Government then we support with concrete deeds, such as sensitive to the environment, help each other, and also there's a will. With the support of the society is certainly the Act of violence that has been formed will be realized and undue can reduce the impact of the violence. In addition, then there was given inputs to families, through an 
understanding of the impact of the danger of violence itself. Therefore, to support the laws that have been established, then the need for support from the various parties, not just the people who know about psychology, but all are obliged to support each other. In the end the violence it will continue to happen because, not care people around so that perpetrators continue to do because no sanctions, and the victim will continue to hurt. Need for supply to the public about violence. In order to make the community better understand what that violence and how to what to do when there is violence around them. In addition, how to protect themselves from violence. Especially children need to be taught how to protect themselves. On the other hand, it is also necessary to give sense to the general meaning of gender and mutual respect of human good sesame male, female, young, and old. Because the thought of a society that is still based on gender that men are more powerful than women is one of the factors in the occurrence of violence.

Need a lot of the roles of various components to handle this case. Governments need to affect cooperation with various parties to solve this case. Among other things, with the community, the academic world, and the media in a systemic, comprehensive, and synergistic. This is because if only the Government are completed, will surely run less smoothly. The Government will protect its citizens by making different rules of protection, but still, many of our lay society will rule or law. Therefore, with the support of the community, the academic world was instrumental for the kids. Especially schools and teachers that is home to both parents and could give guidance to children. As well as the role of the media is very influential in the current era. A lot of people do something due to follow from what we see. However, many current impressions do not educate and teach a bad thing. Therefore, cooperation is needed to resolve this problem. Women and children include mankind that human rights 
had to be protected. Many women especially older children who still have a future so long but with the deprived their rights they can't reach their goals. It would be wonderful if in this life can be addressed cases of violence so that we will not see women and children felt pain either physical or psychic for being the victim of violence. Both women as well as men they have the same rights in life. There is no discrepancy in gender. Because in this life we should appreciate each other.

\section{REFERENCES}

Afrianty, D. (2018). Agents for change: Local women's organizations and domestic violence in Indonesia. Bijdragen tot de taal-, land-en volkenkunde/Journal of the Humanities and Social Sciences of Southeast Asia, 174(1), 24-46.

Alfitri, A. (2020). Protecting Women from Domestic Violence: Islam, Family Law, and the State in Indonesia. Studia Islamika, 27(2), 273-307.

DeKeseredy, W. S. (2020). Violence against Women. Toronto: University of Toronto Press.

Elmira, G. (2020). Jugun Ianfu: The Darkest History of Human Rights Violation. The Indonesian Journal of International Clinical Legal Education, 2(4), 481-490.

Fathul, D., et.al. (2002). Kekeresan Terhadap Istri. Yogyakarta: LKiS Yogyakarta.

Hagan, F. E. (2013). Pengantar Kriminologi. Jakarta: Kencana.

Haryomotko, H. (2007). Etika Komunikasi, Yogyakarta: Kanisius.

Helmi, M. I. (2017). Gagasan Pengadilan Khusus KDRT. Yogyakarta: CV Budi Utama, 2017.

Izat, A. (2020). Contract Marriage in Indonesia: Controversial and Contemporary Issue on Law and Its Impact. The Indonesian Journal of International Clinical Legal Education, 2(4), 407-420. 
Krahé, B. (2018). Violence against women. Current Opinion in Psychology, 19(1), 6-10.

Latifiani, D. (2019). The Darkest Phase for Family: Child Marriage Prevention and Its Complexity in Indonesia. JILS (Journal of Indonesian Legal Studies), 4(2), 241-258.

Putra, S. D. P. (2019). Protection against Indonesian Women Workers. Lex Scientia Law Review, 3(1), 79-86.

Rumble, L., Febrianto, R. F., Larasati, M. N., Hamilton, C., Mathews, B., \& Dunne, M. P. (2020). Childhood sexual violence in Indonesia: a systematic review. Trauma, Violence, E Abuse, 21(2), 284-299.

Setiawan, S., Saifunuha, M. A., Kautsar, J. L., \& Wulandari, C. (2019). Community empowerment on establishment of friendly-village for women and children. Indonesian Journal of Advocacy and Legal Services, 1(1), 5-22.

Setyowati, D., \& Rusdiana, E. (2020). Relevance of Criminal Law Formulation in the Law of Domestic Violence Elimination in Indonesia. JILS (Journal of Indonesian Legal Studies), 5(1), 95-124.

Sitorus, J. C. (2019). Victims of Sexual Abuse: How Does the Law Protect Her?. Unnes Law Journal: Jurnal Hukum Universitas Negeri Semarang, 5(2).

Subhan, Z. (2001). Kekeresan Terhadap Perempuan. Yogyakarta: Pustaka Pesantren.

Wicaksono, M. B. R., \& Lestari, A. (2020). Assessing The Rights of Women Victims of Home Violence During the COVID-19 Pandemic. Lex Scientia Law Review, 4(2), 13-24.

Yantzi, M. (2009). Kekerasan Seksual dan Pemulihan. Jakarta: Gunung Mulia, 2009. 


\section{Conflicting Interest Statement}

All authors declared that there is no potential conflict of interest on publishing this article.

\section{Funding}

None

\section{Publishing Ethical and Originality Statement}

All authors declared that this work is original and has never been published in any form and in any media, nor is it under consideration for publication in any journal, and all sources cited in this work refer to the basic standards of scientific citation. 
Not all men practice violence against women but all women live with the threat of male violence every single day. All over the Earth.

Fuad Alakbarov 